\title{
Relationship between Chronosome Number and Stomata Size in Certain Pineapple Varieties
}

\author{
Alicia R. de Hernández ${ }^{1}$
}

\section{INTRODUCTION}

The pineapple, (Ananas comosus (L.) Merr.) is one of the most promising crops for Puerto Rico. At present, it is the third largest of all export crops, being preceded only by sugarcane. In Puerto Rico its average annual cost of production per acre may run as high as $\$ 500$, and it produces a gross income per acre greater than most other crops $(8)^{2}$.

The main commercial variety planted in the Island is Red Spanish. This variety produces oblong fruit of firm texture, medium size, and with an average weight of 2 to 5 pounds. This variety has been exported to the United States for about 30 years. About 90 percent of the total area in the Island devoted to pineapple is planted to Red Spanish, 8 percent to Smooth Cayenne, and 2 percent to Cabezona.

Smooth Cayenne, the commercial variety of Hawaii, was planted for the first time in Puerto Rico in experiments carried on during 1910 (4). At present, it is planted in small areas on the northern coast. The fruit of this variety is of good quality, somewhat oblong in shape, medium to large in size, and weighs from 5 to 8 pounds.

Cabezona is the third variety of importance in the Island. The fruit of this variety is quite large, sometimes weighing as much as 12 to 15 pounds. Because its fruit is soft and juicy the Cabezona is not suitable for exportation and is consumed locally.

Two other pineapple varieties are of minor economic importance in Puerto Rico, the Negrita and Pan de Azúcar, both of which are used for local consumption only. Negrita is grown in the coffee area, and its fruit is somewhat elongated in form. Pan de Azúcar produces fruit of excellent taste, and similar in shape to those of Negrita. It is commonly found growing sparingly along the coastal regions of the Island.

During the fiscal year 1949-50, the area under pineapple cultivation on the Island was approximately 3,896 acres and the production from this area was $1,152,000$ crates $^{3}(1)$. The best land for pineapple cultivation is

${ }^{1}$ Research Assistant in Cytology, Agricultural Experiment Station, University of Puerto Rico, Río Piedras, P. R. The author is grateful to Mr. P. González-Ríos and Dr. H. E. Warmke for reading and correcting the text and to Mr. I. Bangdiwala for the statistical work.

${ }_{2}$ Numbers in parentheses refer to Literature Cited p. 204.

${ }^{3}$ Approximately 75 pounds per crate. 
distributed along the northern coastal plains of Bayamón, Arecibo, and Manati. There is also a small area in the central part of the Island around the towns of Corozal and Cidra where pineapples are cultivated. Small areas of pineapple are grown in the region of Lajas. (4)

The canned-pineapple exports from Puerto Rico to the United States during the fiscal year 1949-50, totaled about 19,520,21 pounds, with a value of $\$ 2,637,414$. The average price per pound was 14 cents. (1)

The economic importance of pineapple as a crop for the Island is thus well established. However, the commercial varieties actually under cultivation in Puerto Rico are deficient in certain respects, such as low ratooning power and scant slip production. Because of this, a project is under way at this Station for the production of new varieties by means of hybridization.

\section{OBJECTIVES}

As an aid to the breeder in carrying on the above-mentioned project, careful cytological studies of chromosome numbers have been made. Chromosome counts in root tips are time-consuming because of the elaborate laboratory preparations required. If the relation between chromosome number and stomata size in pineapple found by Kerns and Collins (6) were applicable to the material used in Puerto Rico it would help in providing a simpler means for detecting polyploids in pineapple plants. If triploid and tetraploid plants could thus be distinguished, it would be as helpful as, and less time-consuming than actual chromosome counts.

The work here reported was performed to determine whether the abovementioned relation between size of stomata and chromosome number in pineapple plants holds for the varieties available in Puerto Rico.

\section{REVIEW OF THE LITERATURE}

It has been found that many plant characters are correlated with chromosome number. Various measurements, such as pollen-grain size, cell size, size and frequency of stomata, have been used in studies of polyploidy. Kerns and Collins (6), working with pineapple material in Hawaii, found that the stomata and pollen of diploid plants were respectively smaller than those of tetraploids. They worked with the variety Smooth Cayenne.

Sax and Sax (10), making a comparison of diploid and tetraploid races of Tradescantia canaliculata, showed a high degree of correlation between chromosome number and size of stomata. Tetraploid races had larger stomata and larger pollen grains than diploids. Randolph (9) also found a relationship between polyploidy and cell size. He used stomata size to detect induced tetraploids in Zea.

In peppers, the haploid chromosome number was always associated with smaller stomata (3). Blakeslee (2) reported that artificially doubling the 
chromosome number in hemp increased the stomata size. The size of stomata does not vary much between varieties of the same species having the same number of chromosomes. Nebel (7) stated that a difference of approximately 10 percent existed in the average length of stomata as between diploid and triploid apple varieties.

\section{MATERIAL USED}

Leaves of the following pineapple strains were studied:

\section{Strain}

(1) Red Spanish

(2) Eleuthera

(3) Hondureña

(4) Amarelo Boituva

(5) Pan de Azúcar

(6) Natal

(7) Smooth Cayenne

(8) Golden Abachi

(9) Cabezona

(10) Inerme Paulista

(11) Instituto Mayagüez

Common names

Spanish, Black Spanish, Cuban Key Largo, Strawberry Scarlet Key, Largo, Havana

Common names unknown; strain brought from Florida for experimental use

Strain brought from Honduras about 2 years ago for observation

Brought from Brazil

Sugar Loaf

Natal Canning

Kew, Giant Kew, Sarawak, Mexican white, Guatemala Abachi, Abacaxi, Abakka, Abbachi, Bacaxi

Peurto Rico, Bullhead

Brought from Brazil

Brought from Venezuela ${ }^{4}$

\section{PROCEDURE}

Pineapple leaves were obtained from seedlings and from varieties in the Station collection. The material used was always freshly cut. The green leaves were of approximately the same size, stage of maturity, and position on the plant (second whorl from the spindle). All samples were $1 / 2$ inch by $11 / 2$ inches, and were cut from approximately the same position of the selec- ted leaf.

Stomata of pineapple leaves occur on both surfaces; however, those on the upper surface were found more satisfactory for study. Attempts were made to peel the epidermis of the leaves for the study of stomata by using the following materials: 5-percent butyl alcohol, 95-percent ethyl alcohol, methyl alcohol, acetone, and petroleum ether. None of these proved satisfactory, so the usual strip method was used exclusively:

The piece of leaf was peeled off with a scalpel along its coarse side until the transparent epidermis was sufficiently clear. The epidermis was mounted on a slide in a drop of distilled water and covered with a slip. Two-hundred and fifty observations were made for each of the 11 varieties (5).

${ }^{4}$ The common names of the varieties mentioned above are those given by Johnson 
A

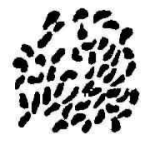

B
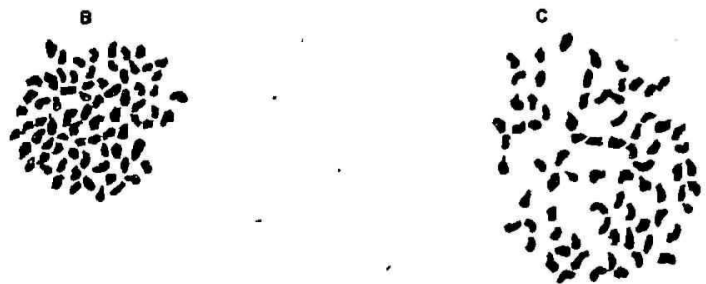

FIG. 1.-Somatic chromosomes of Red Spanish (A) and Cabezona (B and C) varieties of pineapple grown in Puerto Rico.

mentioned above. Fifty specimens of the stomatal apparatus ${ }^{5}$ were measured on each plant.

A binocular microscope with a $20 \times$ hyperplane ocular and a $43 \times$ highpower objective was used. Measurements were made with the help of an ocular micrometer. Drawings of stomata and of chromosomes from root tips were made with the aid of a camera lucida.

\section{RESULTS}

Ten of the strains studied proved to be diploids with 50 somatic chromosomes (fig. 1, A). Average measurements for each variety and the standard error of the mean are shown in table 1.

The size of the stomata studied in 10 diploid strains and 1 triploid strain

"The term "stomatal apparatus" is used to indicate two guard cells and the included opening. 
TABLE 1.-Chromosome numbers and mean lengths and widths, and standard error of the mean of 10 pineapple strains studied

\begin{tabular}{|c|c|c|c|c|c|}
\hline Strain & $\begin{array}{c}\text { Chromosome } \\
\text { number }\end{array}$ & Mean length & $\begin{array}{l}\text { Standard } \\
\text { error of the } \\
\text { mean }\end{array}$ & $\begin{array}{l}\text { Mean } \\
\text { width }\end{array}$ & $\begin{array}{l}\text { Standard } \\
\text { exror of } \\
\text { the mean }\end{array}$ \\
\hline & & Microns & & Microns & \\
\hline (1) Red Spanish & 50 & 25.49 & \pm 0.098 & 22.18 & \pm 0.106 \\
\hline (2) Eleuthera & 50 & 23.32 & \pm .094 & 24.18 & \pm .106 \\
\hline (3) Hondureña & 50 & 24.51 & \pm .091 & 24.16 & \pm .105 \\
\hline (4) Pan de Azúcar & 50 & 23.02 & \pm .082 & 23.31 & \pm .033 \\
\hline (5) Natal & 50 & 23.07 & \pm .082 & 22.17 & \pm .095 \\
\hline (6) Smooth Cayenne & 50 & 20.89 & \pm .063 & 22.73 & \pm .111 \\
\hline (7) Golden Abachi & 50 & 24.32 & \pm .083 & 22.59 & \pm .122 \\
\hline (8) Inerme Paulista & 50 & 22.59 & \pm .083 & 23.73 & \pm .100 \\
\hline (9) Instituto Mayagüez & 50 & 23.90 & 土.095 & 22.54 & \pm .100 \\
\hline (10) Amarelo Boituva & 50 & 23.50 & \pm .087 & 24.13 & \pm .092 \\
\hline General diploid mean & & 23.46 & \pm .028 & 23.16 & \pm .033 \\
\hline Cabezona & 75 & 27.88 & \pm .097 & 26.84 & \pm .113 \\
\hline Least significant difference: & & & & & \\
\hline At the 5-percent point & & 0.18 & & 0.22 & \\
\hline At the 1 -percent point & & .24 & & .29 & \\
\hline
\end{tabular}

of pineapple shows that there is a significant difference between stomata size of diploids and triploids (fig. 2).

The variety Cabezona was the only one found with a chromosome number ( 75 somatic chromosomes, fig. 1, B and C) different from that of all the others. Its stomata were also greater in both length and width $(27.88+$ $0.097 \times 26.84+0.113$ ) than those of the varieties (fig. $2, \mathrm{~A}$ ).
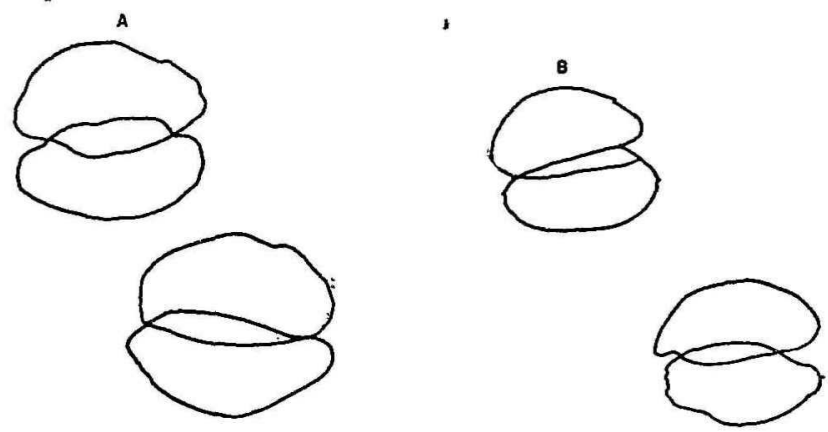

FIG. 2.-Stomata size of Cabezona (A) and Red Spanish (B) varieties of pineapple grown in Puerto Rico. The average size for Cabezona was 29.28 x 28.38 microns, and for the Red Spanish $23.07 \times 22.89$ microns. 


\section{SUMMARY}

A study of the chromosome number as related to stomata size has been reported herein for certain varieties of pineapples grown in Puerto Rico. The diploid strains studied were: Red Spanish, Eleuthera, Hondureña, Pan de Azúcar, Amarelo Boituva, Natal, Smooth Cayenne, Golden Abachi, Inerme Paulista, and Instituto Mayagüez. The triploid strain was Cabezona. The average size of stomata in the diploid strains was found to be $23.46 \times 23.16$ microns. The stomata of the triploid strain averaged $27.88 \times$ 26.84 microns. The difference in the size of the stomata of the diploid and triploid strains was found to be highly significant.

\section{RESUMEN}

Se informan aquí los resultados de un estudio sobre el número de cromosomas en la piña, en relación con el tamaño de las estómatas. Las variedades diploides estudiadas fueron: Española Roja, Eleuthera, Hondureña, Pan de Azúcar, Amarelo Boituva, Natal, Cayena Lisa, Golden Abachi, Inerme Paulista, e Instituto Mayagüez. La variedad triploide fué la Cabezona.

El tamaño promedio para las variedades diploide fué $23.46 \times 23.16$ micrones. Para la variedad triploide $27.88 \times 26.84$ micrones. La diferencia en cuanto al tamaño de las estómatas de las variedades diploide y triploide fué altamente significativa.

\section{LITERATURE CITED}

1. Annual Book of Statistics of Puerto Rico, fiscal year 1949-50, Economic Development Administration, San Juan, P. R.

2. Blakeslee, Albert F., The present and potential service of chemistry to plant breeding, Amer. J. Bot., 26 163-72 1939.

3. Christensen, Hilde M., and Bamford, Ronald, Haploids in twin seedlings of pepper Capsicum annum L., J. Hered. 34(4) 1011943.

4. Coutter, John Wesley, "La Piña" Unión Panamericana Oficina de Cooperación Agrícola, Publicación Agrícola (Nos. 134-135-136) Washington, D. C., Julio 1940.

5. Johnson, Maxwell O., The Pineapple, Paradise of the Pacific Press, Honolulu, Hawaii, 1st. ed., 1935.

6. Kerns, K. R. and Collins, J. L., Chimeras in pineapple, J. Hered. 38(11) 3231947.

7. Nebel, B. R., Characteristics of diploid and triploid apple varieties: I, Measurements of stomata, New York Agricultural Experiment Station, Geneva, N. Y. Proc. Amer. Soc. Hort. Sci. 322541934.

8. Piñero, Manuel, and Bayrón Montalvo, Héctor, Costos de producción de la piña en la zona norte de Puerto Rico 1948-49, Boletín 98, Estación Experimental Agrícola, Río Piedras, P. R., 1951.

9. Randolph, L. F., Cytogenetics of tetraploid maize, J. Agr. Res. 50 591-605 1937.

10. Sax, Karl, and Sax, Holly J., Stomata size and distribution in diploid and polyploid plants, J. Arnold Arboretum 181641937. 